relationship. Complex variable methods are also used in the concluding chapters (amounting to about one-sixth of the whole), which treat the torsion and bending of simple and compound bars of different moduli.

Muskhelishvili's writings cannot fail to make the most vivid impression on every reader by their clarity, their pleasant leisurely style, and their scrupulous attention to detail. There is nothing slipshod in the entire thousand or so pages; every essential point is explained; the exposition is sustained on the highest level even through the appendixes (that on elementary tensor analysis has never been bettered, in the reviewer's opinion). If there is anything to regret, it is that the author's point of view throughout is that of a pure mathematician dealing with a branch of mechanics. The subject is not presented in the round : one aspect only is illuminated. But with what brilliance!

R. HILL

\section{PROBLEMS OF WATER SUPPLY}

Vegetation and Watershed Management

An Appraisal of Vegetation Management in Relation to Water Supply, Flood Control, and Soil Erosion. By E. A. Colman. (Sponsored by The Conservation Foundation.) Pp. xv $+412+16$ plates. (New York : The Ronald Press Company, 1953.) 7 dollars.

A LMOST everywhere in the world there is inA creasing domestic and industrial use of water, and the rising demand is making more and more difficult the task of the water engineer in supplying an adequate quantity of water of good quality all the year round. Leaving aside the doubtful possibility of significant weather modification by cloud seeding, the engineer's raw material is, at most, that part of natural rain and snow not lost to the atmosphere as evaporation from his catchment areas. This evaporation loss is predominantly a transpiration loss that gives an economic return where it is the working capital of the farmer and forester in the growing of crops, so much so that in many parts of the world it is deliberately increased-by irrigationas a necessary condition for human survival. Removal of vegetation is not an acceptable solution of the water problem, even if clearance is restricted to that which is valueless as food or timber. The gain in total annual discharge would bring with it increased flood flow, more severe erosion on the catchment area and in the stream channels, more sediment in reservoirs, and still greater shortage of water in dry weather.

The role of vegetation in hydrology is obviously important, and there is complexity in the study of its many aspects : how it influences the evaporation loss, how it affects the retention of rain and snow on the ground, how it affects the penetration of rain and melt-water into the soil and so to underground storage, how it impedes run-off and restricts erosion. Given such basic information and some unifying ideas it should be possible to consider ways of managing the vegetation to exploit the good and minimize the evil effects. Much of the information does exist, and some of the ideas too; but the literature is very scattered, and there is a need for a comprehensive survey of present knowledge and practice. Dr. E. A. Colman, chief of a research division of the United States Forest Services, has attempted such a survey, but it falls a little short of what it could have been.

The book is written for the non-scientist; but this scarcely justifies Dr. Colman in discarding the precision of language he uses in his scientific papers, to substitute a wordiness that leaves little or nothing to the imagination. The result is that interest flags as case after case is treated on its merits, based on the philosophy that results from one catchment cannot be applied to another in a different climate or with a different kind of vegetation. Scientifically this is a philosophy of despair, but even if it is accepted as being all that is possible or desirable at present, the writing still suffers too much from needless repetition within sections. Drastic pruning would have made this a much better book, a book to be read with pleasure and profit.

The subject is so important that many British readers will be ready to take the profit and let the pleasure go, for this account of American experience in management of catchment areas covers a wide range of climates and vegetation types, including all that are found in Britain and many met in the Commonwealth. There are a long bibliography and two indexes-of authors and subjects - the second of which could usefully have been longer by adding more place names. Several of the famous management experiments, such as Wagon Wheel Gap and Coweeta, are best known by their sites; but site names rarely appear in the index of subjects.

The book is well printed, with its subject-matter admirably illustrated in a collection of good photographs and some clear folded maps of the United States. The maps in black-and-white show the distribution of important hydrological elements; another, in colour, shows the distribution of natural vegetation and the types of farming that have been imposed upon it. By modern standards the price is not exorbitantly high, and the book will prove a useful investment for those with an engineering or scientific interest in water, soil, or vegetation.

H. L. Penman

\section{RELAXATION IN PHYSICS AND ENGINEERING}

\section{Relaxation Methods}

By D. N. de G. Allen. Pp. ix +257 . (London : McGraw-Hill Publishing Company, Ltd., 1954.) 53s. $6 d$.

An Introduction to Relaxation Methods

By F. S. Shaw. Pp. iv + 396. (New York: Dover Publications, Inc., 1953.) 5.50 dollars.

$\mathrm{T}$ HE method of relaxation has now become an established and important technique in mathematical physics and engineering. The object of the present two volumes is to provide a practical introduction to the technique of relaxation and to illustrate it by reference to the various types of problem which have been successfully solved by this means. As Mr. D. N. de G. Allen so well emphasizes in his book, it is an essential feature of relaxation methods that they are extremely flexible and that they leave the maximum of initiative with the computor. For this reason there can scarcely be a completely systematic account of relaxation, since the whole spirit of the method is to avoid systematization. Both these books give an 